\title{
POTENSI FRAKSI ETIL ASETAT DAUN TORBANGUN (Coleus amboinicus L.) DALAM MENINGKATKAN PRODUKSI SUSU, BOBOT BADAN INDUK, DAN ANAK TIKUS
}

\section{(The potency of ethyl acetate fraction of Coleus amboinicus L. leaves in improving milk yield, body weight of rat and their pups)}

\author{
Ade Chandra Iwansyah ${ }^{1,2}$, Muhammad Rizal Martua Damanik ${ }^{2 *}$, Lilik Kustiyah², \\ Muhammad Hanafi ${ }^{3}$ \\ ${ }^{1}$ Pusat Pengembangan Teknologi Tepat Guna, Lembaga Ilmu Pengetahuan Indonesia, Subang 41213 \\ ${ }^{2}$ Departemen Gizi Masyarakat, Fakultas Ekologi Manusia, Institut Pertanian Bogor, Bogor 16680 \\ ${ }^{3}$ Pusat Penelitian Kimia, Lembaga Ilmu Pengetahuan Indonesia, Serpong 15314
}

\begin{abstract}
The aims of the research were to investigate the potential medicine from ethyl acetate fraction of Coleus amboinicus L. for improving milk yield, body weight of rats and its effects on growth of the rat pups. Galactagogue activity was evaluated in terms of quantity of milk produced from the rats treated with ethyl acetate fraction of torbangun leaves (FEA), and commercial milk booster contained 'katuk' leaves extract (AF). Lactating rats $(n=5)$ of Sprague dawley with six pups were fed with FEA and AF in the amount of $30 \mathrm{mg} / \mathrm{kg}$ and $50 \mathrm{mg} / \mathrm{kg}$ body weight, respectively. The feed were given orally every two days and starting from day 2 after giving birth until day 14. The performance of milk production was measured along the experimental period by weight-suckle-weight method. The rates of pups' growth were measured as the weight gain along experimental period. The rats fed with ethyl acetate fraction of torbangun leaves produced higher milk than AF and the control groups, while FEA did not affected the body weight of rats in comparison to the control groups. Ethyl acetate fraction of torbangun leaves was identified to increase milk production by $17 \%$, while AF by $22 \%$. The mean of yields produced by the rats during lactation period for FEA, AF and control were $7.12 \pm 1.16,7.43 \pm 1.04$ and $6.07 \pm 0.85 \mathrm{~g} /$ pups/day, respectively. The FEA administration showed gradually increased of rat pups growth and body weight gain significantly in pups 2-14 days old compared to the control group. The present study reveals the ethyl acetate fraction has the potency as a remedy for improving milk yield without influencing the rats.
\end{abstract}

Keywords: body weight, Coleus amboinicus, fractionation, lactation, rat

\begin{abstract}
ABSTRAK
Penelitian ini bertujuan mempelajari potensi fraksi etil asetat daun torbangun dalam meningkatkan produksi susu, bobot badan induk dan pengaruhnya terhadap pertumbuhan anak tikus. Aktivitas galaktagogum dievaluasi dengan menghitung jumlah produksi susu dari induk tikus laktasi yang diberikan fraksi etil asetat dari daun torbangun (FEA), dan pelancar ASI komersil dari ekstrak daun katuk (AF). Setiap kelompok tikus laktasi ( $\mathrm{n}=5$ ), galur Sprague dawley dengan enam ekor anak tikus, diberikan fraksi etil asetat dari daun torbangun (FEA) dosis $30 \mathrm{mg} / \mathrm{kg} \mathrm{BB}$, dibandingkan terhadap kontrol dan tikus laktasi yang diberikan pelancar ASI komersil dosis $50 \mathrm{mg} / \mathrm{kg}$ BB. Tikus laktasi diintervensi setiap dua hari sekali, dimulai hari ke-2 sampai hari ke-14 masa menyusui. Penampilan produksi susu selama perlakuan dihitung dengan metode sebelum dan sesudah menyusui. Pertumbuhan anak tikus diukur dengan pertambahan bobot badan (PBB) selama periode perlakuan. Kelompok tikus perlakuan fraksi etil asetat dari daun torbangun memproduksi susu lebih tinggi dibandingkan kelompok AF dan kelompok kontrol, sedangkan pemberian FEA tidak mempengaruhi bobot badan induk tikus. FEA dapat meningkatkan produksi susu sebesar 17\% dan AF sebesar 22\% dibandingkan kelompok kontrol. Rataan produksi susu yang dihasilkan oleh tikus selama periode menyusui untuk FEA $(7,12 \pm 1,16$ g/anak/ hari), $\operatorname{AF}(7,43 \pm 1,04 \mathrm{~g} / \mathrm{anak} / \mathrm{hari})$ dan kontrol $(6,07 \pm 0,85 \mathrm{~g} / \mathrm{anak} / \mathrm{hari})$. Pemberian FEA menunjukkan peningkatan pertumbuhan anak tikus secara bertahap dan pertambahan bobot badan secara signifikan di usia anak tikus hari ke 2-14 masa menyusui dibandingkan dengan kelompok kontrol. Penelitian ini mengungkapkan fraksi etil asetat memiliki potensi untuk meningkatkan produksi susu tanpa mempengaruhi bobot induk tikus laktasi dan dapat meningkatkan penampilan pertumbuhan anak tikus.
\end{abstract}

Kata kunci: bobot badan, daun torbangun, fraksinasi, laktasi, tikus

"Korespondensi: Telp:+62 8128159047, Surel: damanik@ipb.ac.id 
Iwansyah dkk.

\section{PENDAHULUAN}

Air susu ibu (ASI) memiliki peranan penting dalam pertumbuhan dan perkembangan anak, terutama di periode sensitif (0-24 bulan). Keterbatasan produksi ASI yang tidak mencukupi merupakan alasan yang sering dilaporkan oleh ibu pada masa awal menyusui (Mannion \& Mansell 2012). Penggunaan senyawa galaktagogum yang berasal dari tanaman merupakan salah satu upaya yang dilakukan dalam mengatasi hal tersebut.

Daun torbangun (Coleus amboinicus L.), famili Lamiaceae, secara empiris telah diketahui bermanfaat untuk meningkatkan produksi air susu ibu (ASI) (Santosa 2001; Damanik et al. 2001). Beberapa penelitian telah membuktikan kebenaran khasiat sebagai pelancar ASI dan kemungkinan efek sampingnya (Santosa 2001; Damanik 2009; Preeja et al. 2011; Doloksaribu et al. 2015a). Pemanfaatan daun torbangun ini masih dalam bentuk daun segar (Damanik et al. 2006), serbuk kering (Doloksaribu et al. 2015b), dan ekstrak etanol sebagai sediaan bahan baku obat (Silitonga \& Situmorang 2013). Penelitian Santosa (2001) melaporkan bahwa dengan pemberian dosis 150 gram daun segar (dalam bentuk sup) kepada ibu menyusui dapat meningkatkan total volume ASI dan berat badan anak di minggu ke-3 dan ke-4. Penelitian tersebut diperkuat oleh penelitian Damanik et al. (2006), pemberian 150 gram daun segar pada ibu menyusui dapat meningkatkan volume ASI sebesar $65 \%$ dari hari ke-14 hingga ke-28.

Penelitian mengenai potensi kelompok senyawa aktif dari daun torbangun dan mekanisme aksinya dalam meningkatkan dan mepelancar ASI masih terus dilakukan. Hal ini perlu dilakukan sebagai upaya pencarian sediaan bahan baku obat yang berasal dari daun torbangun. Analisis kandungan fitokimia dan metabolit sekunder dari ekstrak dan fraksi daun torbangun telah banyak dilaporkan (Patel et al. 2010; Selvakumar et al. 2012; Andarwulan et al. 2014; Suryowati et. al. 2015), akan tetapi senyawa aktif dari proses fraksinasi yang berperan dalam meningkatkan produksi susu belum diketahui bahkan sangat jarang dilaporkan.

Penemuan senyawa aktif di daun torbangun dan mekanisme aksi pengaruhnya terhadap peningkatan sekresi susu melalui "nutrigenomic approach" menjadi arah penelitian ini. Bentuk fraksi daun torbangun dapat dijadikan sediaan obat dengan efek farmakologi tinggi dan efek samping yang rendah. Hal ini dimungkinkan dengan pemisahan senyawa aktif berdasarkan sifat kelarutannya. Penggunaan fraksi etil asetat 62 pada penelitian ini berdasarkan pada sifat pelarut etil asetat yang semi polar, sehingga diharapkan dapat menarik senyawa metabolit sekunder (non polar dan polar) yang berpengaruh atau berperan sebagai laktagogum. Pengujian pada hewan percobaan, terutama dalam proses perbaikan laktasi, dengan menggunakan fraksi etil asetat daun torbangun menjadikan fraksi ini sebagai kandidat obat. Penelitian ini bertujuan untuk mempelajari pengaruh pemberian fraksi etil asetat daun torbangun untuk meningkatkan produksi susu dan bobot badan induk dan anak tikus.

\section{METODE}

\section{Desain, tempat, dan waktu}

Desain penelitian adalah eksperimental dengan rancangan acak lengkap (RAL). Penelitian dilakukan di Laboratorium Bahan Baku Obat dan Alam, Pusat Penelitian Kimia-LIPI, Laboratorium Departemen Gizi Masyarakat FEMA-IPB, dan Laboratorium Hewan, Rumah Sakit Hewan dan Pendidikan, FKH-IPB pada bulan Agustus 2016-Januari 2017.

\section{Bahan dan alat}

Daun Coleus amboinicus (Lour.) diperoleh dari kebun Sukabirus, Megamendung-Bogor, Indonesia ("S 06³9'58,3"; "E 106 52'28,7"; 558 mdpl), ditanam di kebun seluas $180 \mathrm{~m}^{2}$, dengan jarak tanam $20 \mathrm{~cm}$. Daun torbangun yang digunakan berumur panen 60 hari, diambil $15 \mathrm{~cm}$ dari ujung tiap cabang (Sajimin et al. 2011; Andarwulan et al. 2014). Sampel tanaman telah di autentikasi di Herbarium Bogoriensis, Pusat Penelitian Biologi-LIPI, Cibinong Bogor (No.145/IPH.1.01/ II.8/II/2015). Hewan percobaan yang digunakan dalam penelitian ini adalah 15 ekor tikus betina bunting (galur Sprague-dawley) yang dibeli dari PT. Indoanilab-Bogor, dengan besaran sampel ditentukan menurut rumus Federer (1967). Kriteria inklusi pada penelitian ini, yaitu (1) tikus betina bunting galur Sprague-dawley sehat; (2) kebuntingan pertama (H1); (3) keturunan tikus, yang diambil dari populasi tikus yang secara genetis adalah homogen (tersertifikasi); (4) berumur \pm 4 bulan; dan (5) berat badan 200-250 gram. Sedangkan kriteria eksklusi, yaitu (1) tikus sakit atau mati sebelum mendapatkan perlakuan dan (2) induk dan anak mati selama intervensi.

Bahan-bahan kimia yang digunakan adalah Na-CMC, produk pelancar ASI komersial, aquabidest, air destilata, $\mathrm{NaOH}, \mathrm{Na}_{2} \mathrm{CO}_{3}$, gallic acid, quercetin, folin-ciocalteu's phenol reagent; 1,1-diphenyl2-picrylhydrazyl (DPPH) (SigmaAldrich, Singapura) dan $\mathrm{NaNO}_{2}$. Pelarut etanol,

J. Gizi Pangan, Volume 12, Nomor 1, Maret 2017 
etil asetat, n-heksana dan metanol diperoleh dari Merck, Germany.

Peralatan yang digunakan, yaitu kandang tikus beserta kelengkapan pemberian makan dan minum, corong pisah, oven, micro pippet, labu ukur, spuit, jarum oral, gelas kimia, spatula, neraca digital, kertas saring, blender, rotary vacuum evaporator, desikator, kuvet, pisau, gunting, tabung reaksi, mikropipet, oven, tanur, semi micro-Kjeldahl apparatus, vakum flask, volumetrik flask dan sonicator, corong pemisah, spatula, magnetic strirer, vortex, sentrifuse tube, sentrifusa, erlenmeyer, Agilent Technology Cary 60 UVVIS spectrophotometer dan atomic absroption spectophotometer (AAS). Penelitian ini telah mendapatkan persetujuan Komisi Etik Hewan, Lembaga Penelitian dan Pengabdian Masyarakat, Institut Pertanian Bogor (No. 37-2016 IPB).

\section{Tahapan penelitian}

Ekstraksi dan fraksinasi. Daun torbangun yang sudah dibersihkan kemudian dikeringkan pada suhu $50-55^{\circ} \mathrm{C}$, selama perkiraan \pm 2 hari, sehingga diperoleh simplisia kering. Simplisia kemudian dipotong-potong $\pm 50 \mathrm{~mm}$ dan diblender sampai jadi serbuk kasar. Simplisia daun torbangun $(200 \mathrm{~g})$ diekstraksi menggunakan pelarut etanol $(96 \%, 2000 \mathrm{ml})$ dengan cara maserasi selama 24 jam. Maserasi dilakukan berulang kali sampai diperoleh larutan yang bening, kemudian disaring (Whatman No.1) dan dipekatkan dengan rotary evaporator. Ekstrak yang diperoleh disebut sebagai ekstrak etanol. Fraksinasi terhadap ekstrak pekat etanol dilakukan berdasarkan perbedaan kepolaran pelarut organik. Ekstrak etanol $(20 \mathrm{~g})$ dilarutkan dalam pelarut etanol:air (1:1), difraksinasi dengan pelarut $\mathrm{n}$-heksana $(500 \mathrm{ml})$ dengan menggunakan corong pisah sehingga diperoleh 2 fraksi, yaitu fraksi n-heksana dan fraksi etanol-air. Kemudian dilanjutkan dengan fraksinasi antara fraksi etanol-air dengan pelarut etil asetat $(500 \mathrm{ml})$ sehingga dihasilkan 3 fraksi, yaitu fraksi etanol-air, fraksi etil asetat dan fraksi n-heksana. Hasil fraksinasi diuapkan dengan rotary evaporator dan didapatkan ekstrak kental.

Kandungan zat gizi simplisia. Kandungan zat gizi dianalisis berdasarkan metode AOAC (1990), yang meliputi: kadar air, abu, karbohidrat, lemak, protein dan serat kasar. Mineral kalsium, seng, magnesium, kalium dan besi dianalisis menggunakan metode atomic absroption spectophotometer (AAS).

Uji fitokimia. Uji fitokimia, yaitu total fenolik, total flavonoid dan aktivitas antioksidan dianalisis menggunakan metode spektrofotomet- ri. Total fenolik menggunakan metode dari Waterman dan Mole (1994) yang telah dimodifikasi, total flavonoid (Marinova et.al 2005), sedangkan aktivitas antioksidan dengan metode DPPH (Kumaran \& Kuranakaran 2006).

Prosedur intervensi. Hewan coba yang digunakan dalam penelitian ini adalah tikus putih (Rattus norvegicus), galur Sprague-dawley sehat, bunting pertama (H1), umur \pm 4 bulan, bobot badan 250-300 gram, adaptasi selama dua minggu. Empat belas hari hari setelah masa adaptasi sebanyak 15 tikus SD betina secara acak dibagi menjadi tiga kelompok perlakuan (5 ekor per kelompok), dengan memperhatikan keseragaman dan distribusi litter size (6 ekor). Sebelum digunakan sebagai hewan percobaan, semua tikus dipelihara terlebih dahulu selama kurang lebih dua minggu untuk penyesuaian lingkungan, mengontrol kesehatan dengan memberikan obat anti parasit ivermectin (dosis $3 \mathrm{mg} / \mathrm{kg} \mathrm{BB}$ ), berat badan dan menyeragamkan makanannya. Pakan dan minum diberikan secara ad libitum. Ransum standar yang digunakan berdasarkan AIN-93M (Reeves et al. 1993) yang dibeli dari Indonesia Formula Feed (Indo Feed). Kelompok kontrol (KO) sebagai plasebo diberi aquadest. Kelompok AF diberi pelancar ASI komersil (komposisi: 114 mg ekstrak daun katuk, $20 \mu \mathrm{g}$ vitamin $\mathrm{B}_{12}, 25 \mathrm{mg}$ vitamin $\mathrm{B}_{2}, 10 \mathrm{mg}$ vitamin $\mathrm{B}_{1}$ ) dengan dosis 50 $\mathrm{mg} / \mathrm{kg}$ BB per oral. Kelompok FEA diberi fraksi etil asetat daun torbangun dengan dosis $30 \mathrm{mg} /$ $\mathrm{kg}$ BB per oral. Bahan intervensi diberikan secara oral (dengan alat sonde lambung) dengan volume maksimum $1 \mathrm{ml}$. Perlakuan dimulai pada hari ke-2 pasca melahirkan (post partus), dan diberikan setiap 2 hari sekali selama 12 hari.

Produksi susu. Produksi susu dihitung dari selisih bobot badan kelompok anak tikus pada penimbangan sebelum dan setelah menyusui pada induknya. Pengukuran dilakukan setiap dua hari sekali selama 14 hari, dengan anak dipisahksan terlebih dahulu dengan induk selama enam jam (Silitonga 1993). Masing-masing induk menyusui 6 ekor anak dari yang dilahirkan.

Bobot badan induk. Bobot induk tikus diperoleh dari penimbangan bobot induk tikus pada hari ke-2, ke-8 dan ke-14 dengan menggunakan neraca digital $\left(\right.$ Metrology ${ }^{\circledR}$ ) sebelum induk tikus diberikan perlakuan.

Pertambahan bobot badan kelompok anak tikus. Pertambahan bobot badan kelompok anak tikus diperoleh dari bobot kelompok anak sebelum menyusui dari hasil penimbangan yang dilakukan sekali dalam dua hari selama 14 hari (Silitonga 1993; Mahmood et al. 2012). 
Iwansyah dkk.

\section{Pengolahan dan analisis data}

Data hasil eksperimen ditampilkan sebagai rata-rata \pm standar deviasi (SD) dari pengukuran. Data diuji normalitas dan diproses dengan analisis sidik ragam (ANOVA). Jika terdapat perbedaan nyata antara nilai rata-rata antar perlakuan $(\mathrm{p}<0,05)$, maka data dilanjutkan dengan uji lanjut Duncan untuk melihat perbedaan antar tiap perlakuan. Data dianalisis menggunakan software pengolah data Microsoft Excel 2007.

\section{HASIL DAN PEMBAHASAN}

\section{Komposisi gizi simplisia daun torbangun}

Tabel 1 menunjukkan simplisia daun torbangun memiliki kadar air sebesar 10,33\%. Menurut standar farmakologi daun Coleus amboinicus L. WHO-Geneva dan Rajesh et al. (2010), menyatakan standar kehilangan selama proses pengeringan sebesar $10,22 \%$. Kadar abu sering dijadikan parameter kandungan mineral anorganik dalam suatu bahan. Analisis kadar abu dalam sampel simplisia daun torbangun $(14,26 \%)$ lebih tinggi dibandingkan kadar abu yang dilaporkan Suryowati et. al (2015) sebesar $13,48 \%$. Perbedaan ini dipengaruhi oleh berbagai faktor, diantaranya: faktor lingkungan (kesuburan tanah, iklim), umur panen, metode dan lama pengeringan. Kandungan mineral simplisia daun torbangun, yaitu kalsium $(223,3 \mathrm{mg} / 100 \mathrm{~g})$, seng $(6,47 \mathrm{mg} / \mathrm{kg})$, magnesium $(53,15 \mathrm{mg} / 100 \mathrm{~g})$, kalium $(429,5 \mathrm{mg} / 100 \mathrm{~g})$ dan besi $(30,8 \mathrm{mg} / \mathrm{kg})$.

Tabel 1. Kandungan zat gizi daun torbangun (Coleus amboinicus L.) per 100 gram

\begin{tabular}{lcc}
\hline \multirow{2}{*}{ Parameter } & \multicolumn{2}{c}{ Nilai $(\mathrm{g} / 100 \mathrm{~g})$} \\
\cline { 2 - 3 } & $91,38 \pm 0,05$ & $10,33 \pm 0,04$ \\
Kadar air & $1,48 \pm 0,04$ & $14,26 \pm 0,01$ \\
Kadar abu & $0,60 \pm 0,03$ & $5,87 \pm 0,01$ \\
Lemak & $2,02 \pm 0,08$ & $17,36 \pm 0,18$ \\
Protein & $1,09 \pm 0,11$ & $11,13 \pm 0,28$ \\
Serat kasar & $1,15 \pm 0,03$ & $52,18 \pm 0,02$ \\
Karbohidrat & $18,08 \pm 0,71$ & $330,97 \pm 1,67$ \\
Energi (kkal) & & \\
Mineral & $223,5 \pm 0,71$ & - \\
Kalsium (mg/100g) & $6,47 \pm 0,23$ & - \\
Seng (mg/kg) & $53,15 \pm 0,49$ & - \\
Magnesium (mg/100g) & Simplisia \\
Kalium (mg/100 g) & $429,5 \pm 7,78$ & - \\
Besi (mg/kg) & $30,8 \pm 0,14$ & - \\
\hline
\end{tabular}

Nilai merupakan rataan \pm SD dari tiga kali ulangan; (-) tidak dianalisis.

\section{Ekstraksi dan fraksinasi daun torbangun}

Fraksinasi dimulai dengan mengekstraksi simplisia kering daun torbangun dengan menggunakan etanol 96\% (metode maserasi). Ekstrak etanol kasar yang diperoleh kemudian difraksinasi menggunakan pelarut n-heksana dan etil asetat dengan metode partisi cair-cair sehingga menghasilkan tiga fraksi, yaitu fraksi n-heksana, fraksi etil asetat dan fraksi air.

Hasil yang diperoleh menunjukkan rendemen ekstrak etanol kasar sebesar 10,48\%, yaitu dari 200 gram simplisia yang menghasilkan 20.97 gram. Fraksi air daun torbangun secara signifikan memiliki rendemen tertinggi sebesar $29,43 \%$ dari ekstak etanol dibandingkan dengan dua fraksi lainnya, yaitu fraksi n-heksana $(26,37 \%)$ dan fraksi etil asetat $(24,60 \%)(\mathrm{p}<0,05)$.

\section{Fitokimia fraksi etil asetat daun torbangun}

Tabel 2 menunjukkan hasil fitokimia fraksi etil asetat dari daun torbangun mengandung total fenolik $(8,80 \pm 0,01 \mathrm{mg} \mathrm{GAE} / \mathrm{g})$, total flavonoid $(14,19 \pm 0,09 \mathrm{mg}$ QE/g) dan aktivitas antioksidan $(187,18 \pm 0,10 \mathrm{mg} Q \mathrm{QE} / \mathrm{g})$. Hasil aktivitas antioksidan $\left(\mathrm{IC}_{50}\right)$ fraksi etil asetat daun torbangun ini $(161,21 \mu \mathrm{g} / \mathrm{ml})$ lebih tinggi dibandingkan $\mathrm{IC}_{50}$ ekstrak etanol $(247,94 \mu \mathrm{g} / \mathrm{ml})$ (Suryowati et al. 2015).

Tabel 2. Total fenolik, flavonoid dan aktivitas antioksidan fraksi etil asetat daun torbangun (Coleus amboinicus L.)

\begin{tabular}{lc}
\hline \multicolumn{1}{c}{ Parameter } & Nilai \\
\hline Total fenolik (mg GAE/g) & $8,80 \pm 0,01$ \\
Total flavonoid (mg QE/g) & $14,19 \pm 0,09$ \\
$\begin{array}{l}\text { Aktivitas antioksidan }(\mathrm{mg} \mathrm{QE} / \mathrm{g}) \\
\left(\mathrm{IC}_{50}: 161,21 \mu \mathrm{g} / \mathrm{ml}\right)\end{array}$ & $187,18 \pm 0,10$ \\
\hline
\end{tabular}

Nilai merupakan rataan \pm SD dari tiga kali ulangan; GAE $=$ Gallic acid equivalent; QE: Quercetin equivalent.

Kumaran \& Kuranakaran (2006) melaporkan aktivitas antioksidan $\mathrm{IC}_{50}$ ekstrak air daun torbangun sebesar $210 \mu \mathrm{g} / \mathrm{ml}$. Perbedaan nilai aktivitas antioksidan ini dipengaruhi berbagai faktor. Moure et al. (2001), menyatakan bahwa aktivitas antioksidan dipengaruhi oleh faktor lingkungan (letak geografis, umur panen, jenis tanaman dan iklim), penyimpanan, dan faktor teknologi (konsentrasi ekstrak, suhu dan cahaya, ukuran partikel, serta polaritas). Selain itu, faktor suhu penyimpanan ekstrak, jenis pelarut, dan kondisi ekstraksi (metode ekstraksi, pH, suhu ekstraksi, dan waktu ekstraksi) dapat juga memengaruhi aktivitas antioksidan (Maisuthisakul 2012). 


\section{Produksi Susu}

Produksi susu (15 ekor tikus) dihitung dari hari ke-2 sampai hari ke-14 selama masa menyusui setiap hari terhadap bobot berat anak. Pada penelitian ini, perhitungan produksi susu telah dihentikan pada hari ke-16 pasca melahirkan. Pengukuran produksi susu dihentikan pada hari ke-16 dikarenakan anak tikus telah memakan ransum pelet sehingga dapat menimbulkan bias (Mahmood et al. 2012). Tabel 3 menunjukkan bahwa rataan produksi susu tikus selama laktasi hari ke-2 dampai hari ke-14 kelompok kontrol $(6,07 \pm 0,85 \mathrm{~g} / \mathrm{anak} / \mathrm{hari})$, pelancar ASI komersil $(7,43 \pm 1,04 \mathrm{~g} /$ anak/hari), dan fraksi etil asetat daun torbangun $(7,12 \pm 1,16 \mathrm{~g} / \mathrm{anak} / \mathrm{hari})$. Tabel 3 menunjukkan bahwa rendemen susu kelompok fraksi etil asetat dan kelompok AF memberikan perbedaan yang nyata dibandingkan kelompok kontrol $(p<0,05)$.

Tabel 3. Produksi susu hari ke 2-14 masa laktasi setelah tikus diintervensi daun torbangun (Coleus amboinicus L.)

\begin{tabular}{|c|c|c|c|}
\hline \multirow{2}{*}{$\begin{array}{l}\text { Hari ke- } \\
\text { Pasca lahir }\end{array}$} & \multicolumn{3}{|c|}{ Produksi susu (g) } \\
\hline & Kontrol & $\mathrm{AF}$ & FEA \\
\hline 2 & $6,21 \pm 1,47$ & $6,24 \pm 1,43$ & $5,65 \pm 1,54$ \\
\hline 4 & $4,30 \pm 2,85$ & $4,41 \pm 1,65$ & $3,97 \pm 2,07$ \\
\hline 6 & $3,98 \pm 1,58^{\mathrm{e}}$ & $7,61 \pm 2,04^{\mathrm{a}}$ & $6,55 \pm 1,64^{\mathrm{bc}}$ \\
\hline 8 & $3,35 \pm 0,74^{\mathrm{e}}$ & $7,00 \pm 2,10^{\mathrm{a}}$ & $6,20 \pm 2,39^{\mathrm{bc}}$ \\
\hline 10 & $6,70 \pm 2,67$ & $8,89 \pm 0,40$ & $7,55 \pm 1,10$ \\
\hline 12 & $6,69 \pm 1,45^{\mathrm{b}}$ & $3,29 \pm 1,43^{\mathrm{cd}}$ & $7.43 \pm 2,40^{\mathrm{b}}$ \\
\hline 14 & $5,17 \pm 2,35^{\mathrm{cd}}$ & $7,15 \pm 2,28^{b}$ & $5,35 \pm 0,34^{\text {cd }}$ \\
\hline Total & $36,42 \pm 5,10^{\mathrm{d}}$ & $44,60 \pm 6,24^{\mathrm{bc}}$ & $42,70 \pm 6,98^{\mathrm{bc}}$ \\
\hline $\begin{array}{l}\text { Rataan } \\
\text { (g/anak/hari) }\end{array}$ & $6,07 \pm 0,85^{\mathrm{d}}$ & $7,43 \pm 1,04^{\mathrm{bc}}$ & $7,12 \pm 1,16^{\mathrm{bc}}$ \\
\hline $\begin{array}{l}\text { Penambahan } \\
\text { produksi } \\
\text { susu }(\%)\end{array}$ & - & 22 & 17 \\
\hline
\end{tabular}

Total produksi susu tikus selama 12 hari pengamatan masa menyusui kelompok pelancar ASI komersil (AF) dan fraksi etil asetat daun torbangun, masing-masing sebesar $44 \mathrm{~g} / 12$ hari dan $42 \mathrm{~g} / 12$ hari (Tabel 3). Hasil ini menunjukkan nilai rendemen total produksi susu kelompok AF dan kelompok fraksi etil asetat lebih tinggi dibandingkan rendemen total produksi kelompok kontrol (36 g/12 hari) $(\mathrm{P}<0,05)$. Secara relatif, kelompok perlakuan AF dan fraksi etil asetat daun torbangun memproduksi susu lebih besar $22 \%$ dan $17 \%$ dibandingkan kelompok kontrol.
Peningkatan produksi susu tikus selama menyusui kemungkinan berkaitan dengan meningkatnya proliferasi di dalam sel kelenjar susu setelah diberikan intervensi fraksi daun torbangun. Menurut Wall dan McFadden (2011), sekresi susu tikus selama menyusui dipengaruhi oleh populasi sel sekretori dan aktivitas sel. Sebaliknya, penurunan produksi susu dikarenakan penurunan jumlah sel mammae atau pergantian sel (turn over) selama menyusui. Semenjak fraksi etil asetat daun torbangun secara nyata berpengaruh positif terhadap produksi susu tikus, maka dapat diasumsikan bahwa dalam fraksi etil asetat terkandung senyawa aktif yang berfungsi sebagai galaktagogum yang dapat memodulasi hormon-hormon laktogenesis dan laktasi.

Beberapa studi sebelumnya menunjukkan bahwa daun torbangun mengandung komponen fitokimia alkaloid, sterols, triterpenoids, tanin, dan flavonoids (Preeja et al. 2011; El-hawary et al. 2012). Arumugam et al. (2016) menyatakan dalam fraksi etil asetat daun torbangun mengandung komponen aktif $p$-coumaric acid, rosmarinic acid, chysoeriol, eriodictyol, luteolin, quercetin, rutin, 5,4'-dihydroxy-6,7-dimethoxy flavones, 5,4'dihydroxy-3,7-dimethoxy flavones, 5-o-methyl-luteolin, apigenin. Menurut Mohanty et al. (2014), beberapa komponen fitokimia, seperti polifenol, tanin dan alkaloid memiliki pengaruh untuk meningkatkan produksi susu, konsentrasi protein susu dan tingkat ovulasi, meningkatkan pencernaan protein dan membantu dalam mengeluarkan air susu. Selain itu, penelitian mengenai pemberian senyawa flavonoid rutin dapat mempromosikan pengeluaran hormon prolaktin (PRL) dan growth hormon (GH), upregulated ekspresi gen reseptor hormon prolaktin (PRLR) dan GHR, dan merangsang perkembangan payudara pada tikus vasektomi (Xu dong et al. 2012).

\section{Penampilan bobot Induk selama menyusui}

Secara umum asupan pakan bagi tikus menyusui pada setiap kelompok perlakuan mendapatkan asupan zat gizi atau energi yang sama. Gambar 1 menunjukkan bahwa pemberian fraksi etil asetat daun torbangun dan pelancar ASI komersil (AF) tidak memberikan perbedaan yang signifikan dibandingkan kelompok kontrol $(p>0,05)$. Kecenderungan penurunan bobot badan induk berhubungan dengan pertambahan bobot badan anak. Hal ini dapat dilihat pada hari ke-8, ketika terjadi penurunan BB induk, terjadi pertambahan BB anak (Tabel 4). 
Iwansyah dkk.

\section{Pertumbuhan dan penambahan bobot anak tikus}

Susu dikonsumsi anak tikus, umumnya digunakan untuk pertumbuhan dan pemeliharaan. Pembatasan jumlah dan keseragaman ukuran anak tikus yang dilakukan bertujuan agar kebutuhan susu tercukupi untuk pertumbuhan yang maksimal. Mahmood et al. (2012), pertumbuhan tikus sangat dipengaruhi oleh kuantitas susu yang tersedia selama masa menyusui.

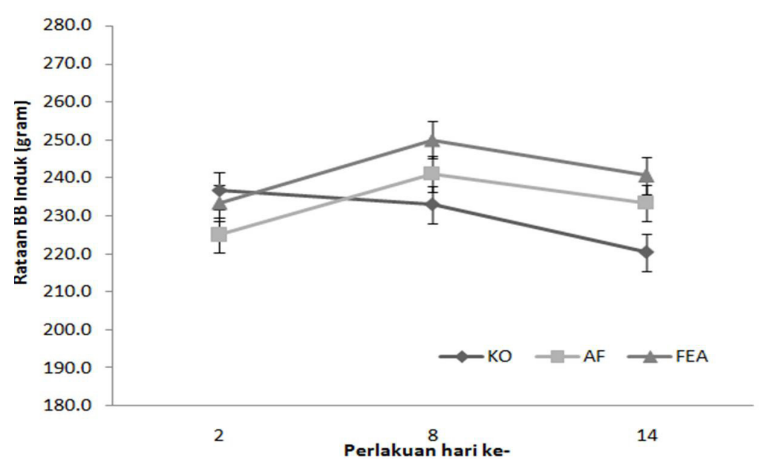

Keterangan: $\mathrm{KO}=$ kontrol; $\mathrm{AF}=$ pelancar $\mathrm{ASI}$ komersil;

$\mathrm{FEA}=$ fraksi etil asetat. Nilai merupakan rataan $\pm \mathrm{SD}(\mathrm{n}=5)$.

Gambar 1. Rataan bobot badan induk hari ke 2-14 selama masa intervensi.

Berat badan anak tikus selama 10 hari pengamatan menunjukkan penambahan berat badan secara linier (Gambar 2). Slope regresi linier dihitung sebagai nilai $R^{2}$. Estimasi nilai $R^{2}$ dari masing-masing kelompok, yaitu kontrol $(0,992)$, pelancar komersil $(0,966)$ dan fraksi etil asetat $(0,988)$. Perubahan bobot badan anak tikus selama periode menyusui untuk semua perlakuan dapat dilihat pada Gambar 2.

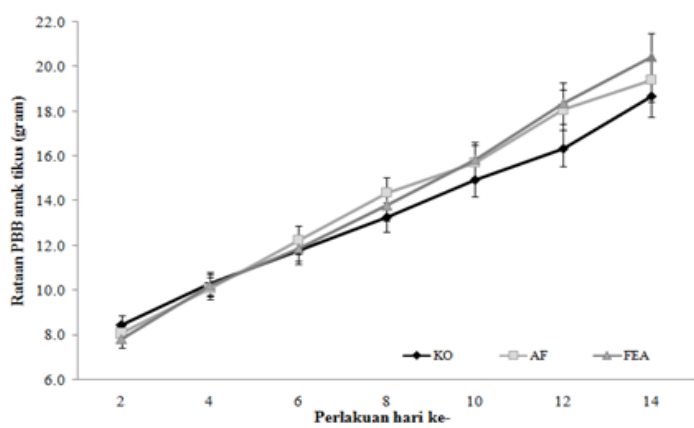

Keterangan: $\mathrm{KO}=$ kontrol; $\mathrm{AF}=$ pelancar $\mathrm{ASI}$ komersil; $\mathrm{FEA}=$ fraksi etil asetat. Nilai merupakan rataan $\pm \mathrm{SD}(\mathrm{n}=5)$.

Gambar 2. Rataan bobot badan anak tikus hari ke 2-14 selama masa intervensi.

Respons positif produksi susu induk tikus dari fraksi etil asetat daun torbangun memberikan gambaran yang serupa pada responsnya terhadap penambahan bobot badan anak tikus(PBB). Res- pons fraksi etil asetat daun torbangun terhadap PBB anak tikus disajikan pada Tabel 4.

Respons PBB anak tikus setelah induk mendapatkan perlakuan fraksi daun torbangun dari hari ke-2 sampai hari ke-14 menunjukkan peningkatan yang signifikan dibandingkan dengan kelompok kontol $(\mathrm{P}<0,05)$. Rataan penambahan bobot badan anak tikus kelompok fraksi etil asetat tertinggi dibandingkan kelompok pelancar ASI komersil dan kontrol. Pengaruh pemberian fraksi etil asetat daun torbangun terhadap pertambahan bobot badan anak sesuai dengan produksi susu induk. Hal ini sejalan dengan penelitian Suprayogi et al. (2015), menyatakan peningkatan rataan PBB anak berkorelasi nyata dengan peningkatan produksi susu ketika diberi fraksi heksan daun katuk.

Tabel 4. Rataan pertambahan bobot badan (PBB) anak tikus pada usia 2-14 hari selama masa induk diintervensi

\begin{tabular}{lccc}
\hline \multirow{2}{*}{$\begin{array}{c}\text { Usia anak } \\
\text { tikus (hari) }\end{array}$} & \multicolumn{3}{c}{ PBB $(\mathrm{g})$} \\
\cline { 2 - 4 } & Kontrol & AF & FEA \\
\hline $2-7$ & $3,93 \pm 0,16^{\mathrm{c}}$ & $4,21 \pm 0,52^{\mathrm{b}}$ & $5,04 \pm 0.72^{\mathrm{a}}$ \\
$7-14$ & $5,87 \pm 2,97^{\mathrm{b}}$ & $7,37 \pm 0,24^{\mathrm{a}}$ & $7,62 \pm 0.7^{\mathrm{a}}$ \\
\hline
\end{tabular}

Nilai merupakan rataan $\pm S D ; a>b>c$, huruf yang sam dalam baris sama = tidak berbeda nyata; AF: pelancar ASI komersil; FEA: fraksi etil asetat; $(n=5)$.

\section{KESIMPULAN}

Pemberian fraksi etil asetat daun torbangun (FEA) memberikan respons positif terhadap rataan dan total produksi susu selama 12 hari laktasi. Fraksi etil asetat meningkatkan produksi susu, pertumbuhan dan penambahan bobot anak tikus, tetapi tidak mempengaruhi penampilan bobot induk. Rataan produksi susu kelompok FEA tidak berbeda dibandingkan kelompok AF, akan tetapi berbeda nyata terhadap kelompok kontrol. Kelompok senyawa semi-polar dalam fraksi etil asetat dapat dijadikan pertimbangan sebagai senyawa pemicu produksi susu.

\section{UCAPAN TERIMA KASIH}

Penulis mengucapkan terima kasih kepada Kementerian Riset dan Teknologi dan Pendidikan Tinggi, Republik Indonesia (Kemenristekdikti RI) atas bantuan finansial (03/D-SDI/PTB/X/2013) dan kepada Institut Pertanian Bogor (IPB) dan Lembaga Ilmu Pengetahuan Indonesia (LIPI) untuk dukungan akses dan teknis. 


\section{DAFTAR PUSTAKA}

Andarwulan N, Yuliana ND, Hasna E, Aziz SA, Davis TD. 2014. Comparative analysis of three Torbangun clones (Plectranthus amboinicus (Lour.) spreng based on phenotypic characteristics and phenolic content. American J. Plant Sciences 5:3673-3683.

[AOAC] Association of Official Analytical Chemistry. 1990. Official Methods of Analysis. Association of Official Analytical Chemist. Arlington, Virginia: AOAC.

Arumugam G, Swamy MK, Sinniah UR. 2016. Review: Plectranthus amboinicus (Lour.) Spreng: botanical, phytochemical, pharmacological and nutritional significance. Molecules 21:369-95.

Damanik R. 2009. Torbangun (Coleus amboinicus Lour): a Bataknese traditional cuisine perceived as lactagogue by Bataknese lactating women in Simalungun, North Sumatera, Indonesia. J. Hum Lact 25(1): 64-72.

Damanik R, Damanik N, Daulay Z, Saragih $\mathrm{S}$, Premier R, Wattanapenpaiboon N, Wahlqvist ML. 2001. Consumption of bangun-bangun leaves (Coleus amboinicus Lour) to increase breast milk production among Bataknese women in North Sumatera Island, Indonesia. APJCN 10(4): 67.

Damanik R, Wahlqvist ML, Wattanapenpaiboon N. 2006. Lactagogue effects of Torbangun, a Bataknese traditional cuisine. APJCN 15(2):267-74.

Doloksaribu TH, Syarief H, Damanik MRM, Marliyanti SA. 2015a. Pertumbuhan bayi dan pemberian asi eksklusif oleh ibu penerima konseling menyusui dan makanan tambahan torbangun. J Gizi Pangan 10(2):77-84.

Doloksaribu TH, Syarief H, Damanik MRM, Marliyanti SA. 2015b. The development of torbangun flour-based functional supplementary food for breastfeeding mother. Int J Sci: Basic Appl Res 1:348-55.

El-hawary SS, El-sofany RH, Abdel-Monem AR, Ashour RS. 2012. Phytochemical Screening, DNA Fingerprinting, and Nutritional value of plectranthus amboinicus (Lour.) Spreng. Phcog J 4:10-13.

Frederer WT. 1967. Experimental design: theory and application. Calcutta(IN): Oxford \& IBH Publ. Co. 591 pp.

Kumaran RJ, Kuranakaran. 2006. Antioxidant and free radical scavenging activity of an aqueous extract of Coleus aromaticus. Food Chemistry 97:109-14.

Mahmood A, Omar MN, Ngah N. 2012. Galactagogue effects of Musa x paradisiacal flower extract on lactating rats. Asian Pac J Trop Med :882-886.

Maisuthisakul P. 2012. Phenolic constituents and antioxidant properties of some thai plants, phytochemicals - a global perspective of their role in nutrition and health. Ed. Venketeshwer Rao.

Mannion C, Mansell D. 2012. Breastfeeding selfefficacy and the use of prescription medication: a pilot study. Obstet Gynecol Int 2: 562704.

Marinova, Ribarova F, Atanassova M. 2005. Total phenolic and total flavonoids in Bulgarian fruits and vegetables. Journal of the University of Chemical Technology and Metallurgy 40(3):255-60.

Mohanty I, Senapati MR, Jena D, Behera PC. 2014. Ethnoveterinary importance of herbal galactogogues - a review. Veterinary World 7(5):325-330.

Moure A, Cruz JM, Franco D, Domingguez JM, Sineiro J, Dominguez H, Nunez MJ, Parajo JC. 2001. Review: natural antioxidant from residual sources. Food Chem 72:145171.

Patel R, Mahobia N, Waseem N, Upwar N, Singh S. 2010. Phyto-physicochemical investigation of leaves of Plectranthus amboinicus (Lour) Spreng. Phcog J 2(13):536-542.

Preeja G, Pillai, Suresh P, Aggarwal G, Doshi G, Bhatia V. 2011. Pharmacognostical standardization and toxicity profile of the methanolic leaf extract of Plectranthus amboinicus (L.) Spreng. J Appl Pharm Sci 1(2):75-81.

Rajesh P, Latha S, Selvamani P, Rajesh K. 2010. Capparis sepiaria Linn-pharmacognostical standardization and toxicity profile with chemical compounds identification (GC-MS). Intl J Phytomedicine 2:71-79.

Reeves PG, Nielsen FH, Fahey GC Jr. 1993. AIN-93 Purified diets for laboratory rodents: final report of the american institute of nutrition ad hoc writing committee on the reformulation of the AIN-76A rodent diet. J Nutr 123(11):1939-1951.

Sajimin ND, Purwantari E, Sutedi, Oyo. 2011. Effect of cutting interval to productivity and quality of Bangun-bangun (Coleus amboinicus $\mathrm{L}$ ) as aforage promising commodity. JITV 16(4):288-93. 
Santosa CM. 2001. Khasiat konsumsi daun bangun-bangun (Coleus amboinicus L) sebagai pelancar sekresi air susu ibu menyusui dan pemacu pertumbuhan bayi (Tesis). Bogor: Sekolah Pascasarjana IPB.

Selvakumar P, Naveena E, Prakash BD. 2012. Studies on the antidandruff activity of the essential oil of Coleus amboinicus and Eucalyptus lobules. Asian Pac J Trop Biomed: 715-719.

Silitonga M. 1993. Efek laktogogum daun jinten (Coleus amboinicus L) pada Tikus Laktasi (Tesis). Bogor: Sekolah Pascasarjana IPB.

Silitonga M, Situmorang E. 2013. The effect of ethanol extract Coleus ambonicus L on antibody titer of white rats (Rattus norvegicus) trough SRBC as antigen. Prosiding The $2^{\text {nd }}$ International Conference on Multidisciplinary Research (ICMR) (hlm. 312318), October 2-4, Banda Aceh: Indonesia.

Suprayogi A, Kusumorini N, Arita SED. 2015. Fraksi heksan daun katuk sebagai obat un- tuk memperbaiki produksi susu, penampilan induk dan anak tikus. J Veteriner 16(1):88-95.

Suryowati T, Rimbawan, Damanik R, Bintang M, Handharyani E. 2015. Identifikasi komponen kimia dan aktivitas antioksidan dalam tanaman torbangun (Coleus amboinicus Lour). J Gizi Pangan 10(3):217-224.

Wall EH, McFadden TB. 2011. Triennial lactation symposium, a local affair: how the mammary gland adapts to changes in milking frequency. J Anim Sci, 90(5):1695-1707.

Waterman FG, Mole S. 1994. Analysis of Phenolic Plant Metabolites. Oxford : Blackwell Scientific Publications.

Xu-dong G, Qi-yu D, Yue-ying W, Yan T, Kaidong D, Xin-jian W, Tong F, Gui-long Y. 2012. The effect of administration of rutin on plasma levels of estrogen, prolactin, growth hormone and gene expression of their receptors in mammary glands in ovariectomized rats. Journal of Integrative Agriculture 11(10):1700-1706. 